\title{
Teaching Writing Using Google Apps For Education (GAFE)
}

\section{Afrianto Daud}

Faculty of Teachers Training and Education Universitas Riau, Pekanbaru, Indonesia

afrianto.a@lecturer.unri.ac.id

\begin{tabular}{|c|c|}
\hline Article Info & Abstract \\
\hline Received : 2019-01-01 & This paper presents how an English teacher can use Google Apps for \\
\hline Accepted : 2019-01-15 & Education (GAFE) technology to enhance the quality of teaching \\
\hline Published : 2019-01-28 & writing in the context of teaching English for students in a higher \\
\hline $\begin{array}{l}\text { Key words: teaching writing, } \\
\text { Google apps for education, online } \\
\text { learning, blended learning }\end{array}$ & $\begin{array}{l}\text { Google applications which can be used for (Engliah) teachers to } \\
\text { enhance their teaching. It specifically reports a technology based } \\
\text { teaching technique which has been practiced in a teacher education } \\
\text { program in a university in Indonesia. It explores the prerequisite } \\
\text { condition to use this application. This is followed by detailed stages } \\
\text { of using this application, particularly in teaching writing: what } \\
\text { teachers and students should do during the lesson. The explanation } \\
\text { is enriched by a discussion on some possible challenges an English } \\
\text { teacher or students may face in the field. The discussion is finally } \\
\text { closed by proposing some suggestions on how to make use the } \\
\text { technology and how to deal with the potential problems. }\end{array}$ \\
\hline
\end{tabular}

\section{Introduction}

As the world currently develops and changes rapidly, it is important for (English) teachers to keep updated and familiar with any development in the information and communication technology (ICT). This familiarity would enable the teachers to make use of the technology to enhance their teaching in the classroom. This is also because challenges faced by today's teachers may be totally different from teachers in the past. Students' needs and behavior regarding the use of technology, for instance, are different from what the teachers used to see many years ago. Therefore, today's teachers could not approach their students with ways their old teachers used to do in the past. As Chamberlain (2012) in Neumann (2014), maintains, "Education is evolving due to the impact of the Internet. We cannot teach our students in the same manner in which we were taught. Change is necessary to engage students ...."

Chamberlain's concerns is self evident as the technology revolution in education has brought about new challenges and new opportunities to educators all over the world. The technology is not only potential to accelarate students' learning, for instance, it could also challenge teachers how to make use the students as one of important learning resources. Because of their familarity with the high-tech devices, it is likely that some students today could have accessed particular lessons long before their teachers the materials in the classroom. Today's kids are indeed awsome in a sense that their ability to explore the technology. This is relevant to a term which was first coined and popularized by an education consultant, Prensky (2001), saying that majority of students today are considered as 'digital native'. This refers to the fact that they have been familiar with any electronic devices, including the use of mobile phones and the internet since they were little kids. Therefore, teachers are supposed not to be left behind their students in using this technology. 
In addition, there are at least two major reasons why an educator needs to make use of the digital technology for his or her teaching. First, from a practicality point of view, there are some conditions when teachers can not physically attend at their traditional classrooms. It may because of their high mobility or their duty outside of town. Some university lecturers may be so active outside campus like attending conferences overseas, or doing other academic duty or activities out of the town. For this reason, they have to leave their classes and the students have to wait until they return to campus. This is definitely not fair for the students, especially if the lecturers have to be away for quite a long time.

Some unexpected situations such as natural disaster may also have hindered the traditional classroom. When haze problem attacked Sumatera Island two years ago, for instance, all schools and universities in Riau province were closed for more than two months. In this context, I would argue that if the schools, universities, teachers, and lecturers had been familiar with how to use Google Apps for Education, they would have been able to keep their class going through virtual classrooms regardless all the constraints.

Furthermore, from theoretical perspectives, introducing an online or virtual classroom would bring some advantages for the teaching and learning process. Some studies suggest that a virtual learning environment can be conducive to language learning as online learning appears to reduce student self-awareness and social anxiety which, in turn, results in increased language production (e.g. Bradley \& Lomicka, 2000; Wallace, 1999; Carnevale, 2003; Roed, 2003 quoted in Lewandowski, 2015).

This virtual classroom activity can be also considered as a way for teachers to have a blended learning (Whittaker, C. and B. Tomlinson, 2013). In the context of English Language Teaching (ELT), 'blended learning' is the term most commonly used to refer to any combination of face-to-face teaching with computer technology (online and offline activities/materials). Therefore, it will be a good idea for teachers to have a virtual classroom as an addition or variation to their traditional teaching mode during their academic calendar. In practice, apart from some practical reasons as aforementioned, to do this blended learning, teachers should plan in advance to have some virtual classroom by using the Google Hangouts. A variation is indeed a good idea in terms of maintaining students' interests and enables them to have a new learning experience.

To support educators all over the world, in last six years or so as part of its Google For Education program Google has released many applications which can be used by teachers to enhance their information technology (IT) based teaching and learning. These applications are now available for free. These include Gmail, Google Doc, Google Drive, Google Sheet, Google Google Talk, Google Classroom, Google Hangouts on Air, and many others. This paper reports how I as an English lecturer in a university in Indonesia has introduced the use of these apps in my teaching, particulary in teaching writing for higher degree students.

\section{Teaching Writing Using Google Apps for Education}

This paper is written on the basis of my personal experience in teaching writing for pre-service English teachers at English Education department of the Faculty of Teachers Training and Education of Universitas Riau, Indonesia. This is the faculty which aims to prepare the future of Indonesian teachers (including English teachers) who will teach in either primary or secondary level accross the country. The students I was teaching were second year students who were taking Writing 2 subject. This subject is the continuation of Writing 2 class and a prerequisite class for the next classes (Writing 3 and Academic Writing).

A writing teacher in a university level will normally introduce his or her students with five important stages of writing process, especially for writing an academic text, starting from 
pre-writing activities, whils-writing activities, to post-writing activities. The pre-writing activities include brainstorming, drafting, and free writing techniques to gather ideas. The whilst-writing activitie are normally marked by activitis such as developing ideas into paragraphs, writing up sentences, developing main ideas and supporting details, looking at issues of coherence and cohession, as well as language issues. In the post-writing activities, teachers would remind students to do activities like revising, editing, and proofreading the text they have written (See Zemach and Romisek, 2005; Langan, 2005) .

In a traditional class, writing teachers normally do the activities by relying on manual activities where teachers and students usually work with papers and pencil as tools. After explaining some concepts of writing, the teachers would ask the students to write on papers and the teachers would provide feedback on the students' papers. The discussion and or feedback about students' writing is usually conducted through face to face communication.

Unlike this traditional class, my writing class is getting paperless and almost borderless as I made use of the google apps for education as the main media to facilitate learning activities in my writing class. Using these apps has not only enabled me to interact with students at any times I like, but also have made it possible for every students and myself as their techer to provide feedback on students' piece of writing at any time I like. Details of the activities are explained as the following.

\section{Stage 1: Setting up the stage and registering on Google Account.}

Before getting started, there are some technical issues you need to make sure in advance. If you have PCs with latest configurations connected to a reliable internet network, it would be an ideal classroom atmospher for your class to make use of Google Apps for Education for teaching writing. Otherwise, you have to remind students to bring their own laptops or other devices, such as their Ipads or smatphones to your class. Only with these devices they can follow all activities you have planned both in clasroom activities or at home. In the case of my class, mostly the students work with their own electronic devices.

Apart from having computers with the latest configurations, you also need to have a high speed internet connection. Your internet connection should work even without power supply. A reliable internet connection and power provision are extremely important for the maximum use of this Google Apps for Education. In addition, you need to have an alternate source of power to ensure continuous transmission even during power outages.

To be able to use Google Apps for Education, the first important thing you need to do is that you must have a Google account or Gmail. You may use your personal Gmail or your business account to sign in. This is like a passport to access all Google Application. If you do not have it yet, you can sign up one for free. Signing up is an easy process. Once you have a Google account, you can access and use all google applications on your smartphone or tablet.

To be able to use this Google Apps for Education for teaching purposes, you also need to ask your students to have a Google account and install the necessary applications in their laptops or other devices. Once you and your students are ready with the isntalled app, you can now invite your students to work with your either through email, google drive, or google classroom.

When you have a gmail account, you can now log in and will see some google applications listed on the top right side of your gmail interface (See Figure 1). Once you see it, you can now explore the applications. 
Figure 1. Gmail Inbox Interface

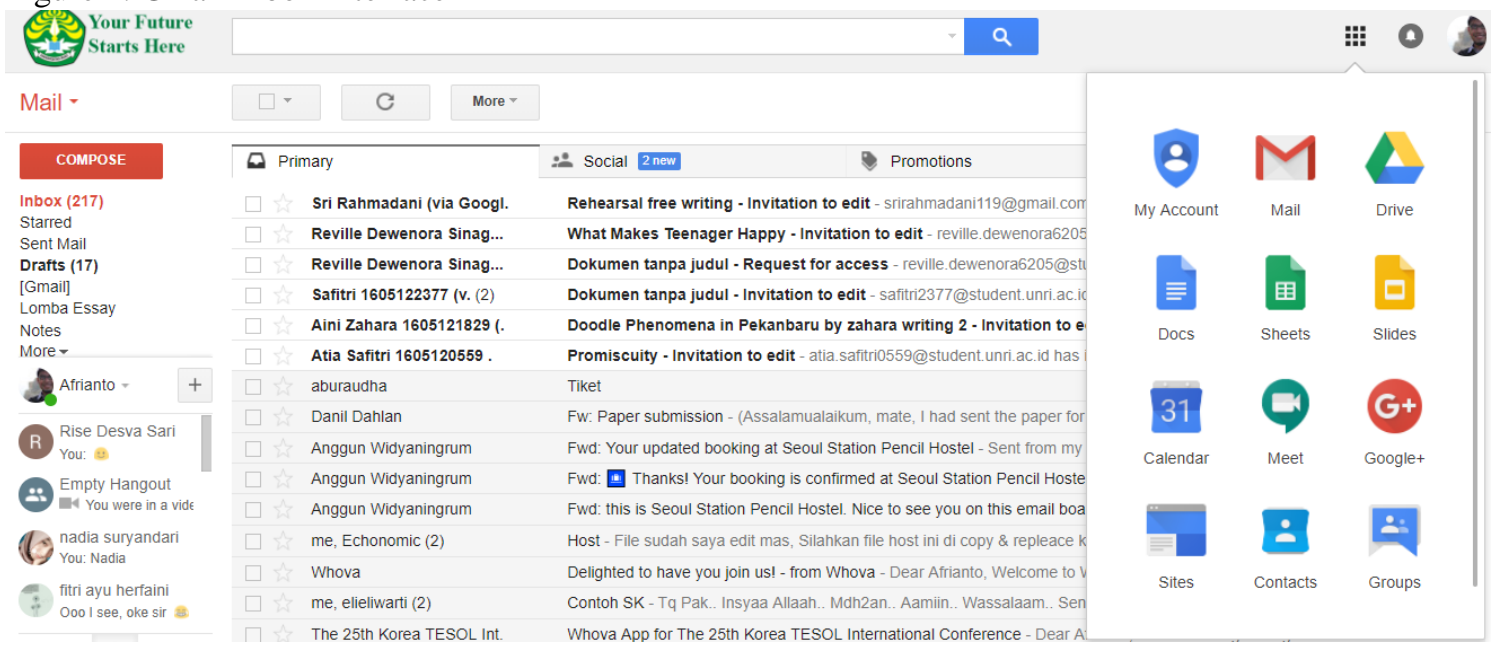

\section{Stage 2: Working with Google Doc and Google Drive}

The first two applications I introduced to the students in my writing class were Google Doc and Google Drive. Google drive is simply like Microsoft Office for word document and Google Drive is like iCloud drive owned by Google to store your documents online. Rather than writing on a piece of paper, I asked the students to type their writing draft, for instance, on their Google Doc and save it on their Google Drive. Through Google Drive, the students can also easily share the file to me as their lecturer or to their friends. Sharing file with friends then enable them to practice peer-editing activities as well as getting feedback from their friends.

Another good thing from Google Doc is that students' writings are automatically saved by the system in every two seconds, so the students do not need to worry of loosing any files, like what sometimes happen if they work manually or with Microsoft Office Word document. Regarding the Google drive, the students have at least 15 GB free storage if they work with their personal Gmail account. Much more storage will be given if they work with their university based email account. With this relatively big storage, students can save lots of file there and the files there will remain there forever as far as Google still exists. They can build their own folders there. They can update any files at any time from any devices they have as far as they can go online.

\section{Stage 3: Peer-Editing and Teachers' Feedback.}

The importance of peer editing and or peer feedback in the process of teaching writing has been mentioned by many researchers and practicioners in the field of teaching writing (See for instance Bijami M, Kashef S \& Nejad M, 2013; Tusino, 2013; Lundstrom K \& Baker W, 2009). Their studies support the ideas that peer-editing or peer-feedbcak provide a significant point in improving students' writing quality. This is not only the case for the students provided feedback but also fo those who provide feedback.

The same story goes to the teachers' feedback on students' writing. Reseracher have found that feedback from teachers about students' writing will significantly improve sudents' writing quality. In particular, the feedback would boost students' confidence in writing process, even a minimal feedback given to students was helpful and provided a platform for the students to do self-revision (Ismail, Hassan, \& Maulan, 2008), and it defenitely resulted in overall essay improvement (Paulus, 1999).

The peer editing and teachers feedback is fully conducted online and paperless. By using Google Doc and Google Drive, students can share their draft to their friends as well as to their 
teacher. They can read, suggest and changes, or edit their peer's draft to make it better. Through the shared file, teacher can control the students' activity to make sure if the peer editing process has been running as planned and as expected. At the same time, the teacher can provide suggestions and feedback on students' writing. The students' can see the suggestions and feedback immediatley, although the teachers and the student do not have face to face interaction (Please see Figure 2 belom as a sample of my feedback on a student's piece of writing).

Figure 2. A Sample of Teacher's Feedback via Google Doc

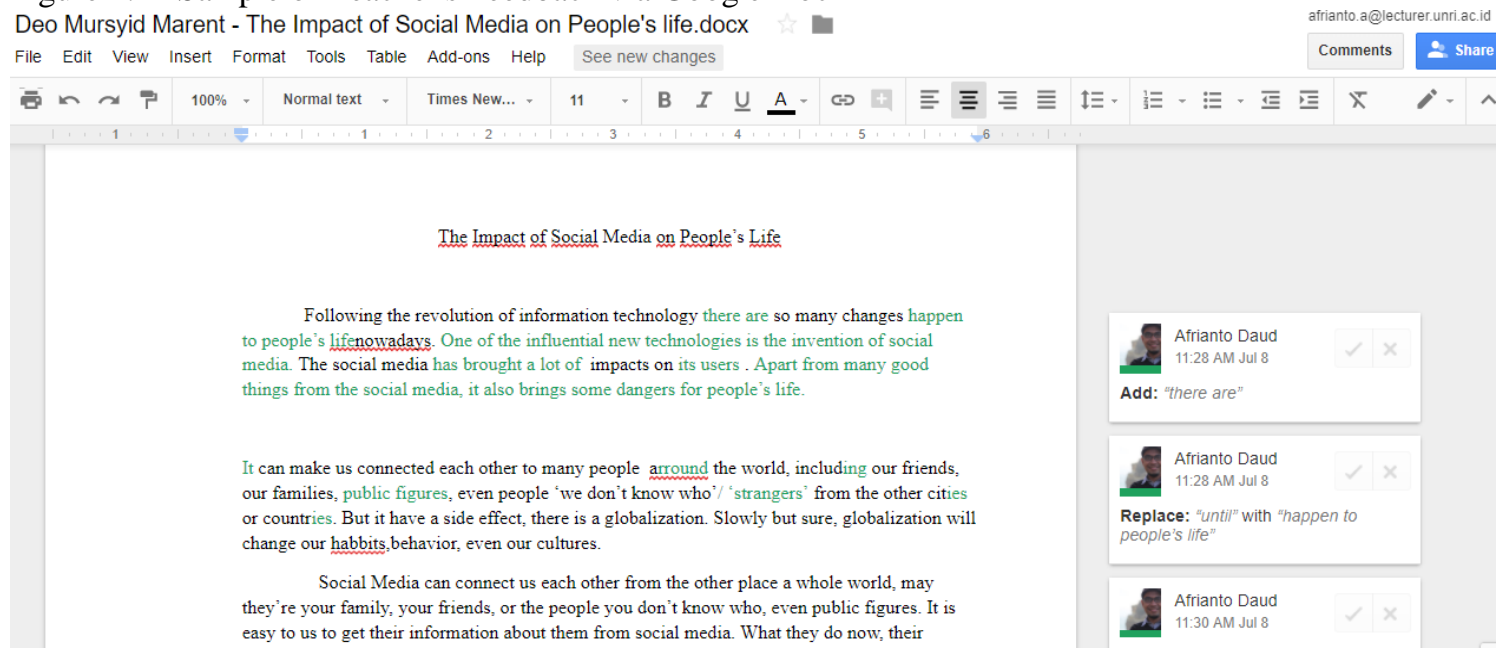

\section{Stage 4. Working with Google Classroom}

Google Classroom is a handy application that can be used by teachers to mange his or her class online. The application enables teaches to inteact with their students at any time. The teachers can post learning materials, annoucement, and assignment there. This is like a virtual class where teachers can communicate with the students online. The teachers can even mark students' works, provide feedback, and score for students' works (see Fugure 3 for a sample of Google Clasroom interface).

Figure 3. Interface of a Google Clasroom

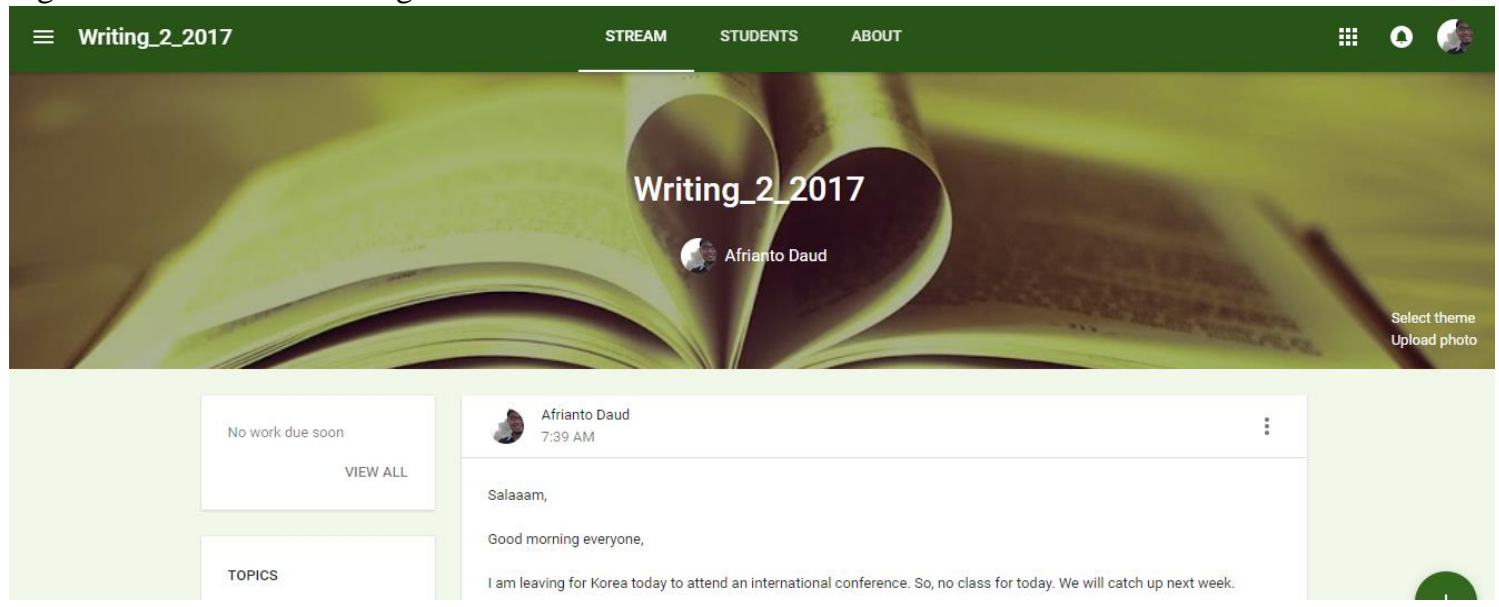

In my writing class, this Google Classroom is used as the main platform for organising classs. All of my students were registered in the classroom. They can access all learning materials I uploaded there. I reach my students through this virtual classroom by posting an annoucement, an assignment, or some links they can learn to enrich their understanding of certain topics of writing. What I found most interesting from the Google Classroom is that I can 
manage the assigment very effectively. I can post the assignment, set the deadlines, see students who have done the assignment and those who have not (see Figure 4). I can even check the students' writing and provide online feedback or provide scores for their works at anytime I like.

Figure 4. Managing Students' Assignment in Google Classroom

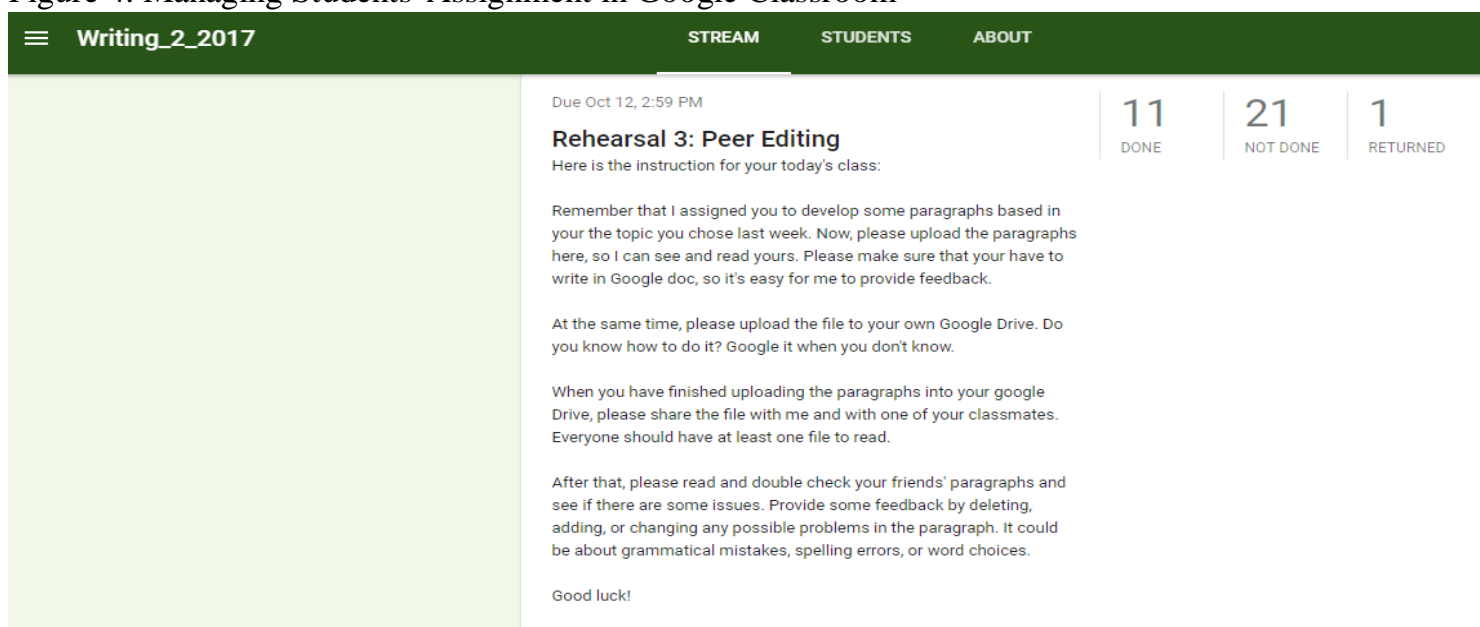

\section{Stage 5. Reach the students via Google Hangouts}

Google Hangouts is an excellent service that enables both one-on-one and group chats with several people at a time (Lander, 2014). This is one of the services that would enable teachers, including English teachers, to have a virtual classroom. Apart from its feature for video based comunication, users can also still hold a communication through this app using only the textual chat functionality, like texting features or they can add voice.

Lander (2014) describes that there are two kinds of Google Hangouts. One is just Hangouts which are more of an engagement tool with friends, very much like Google chat and Skype. There is also another great feature called Hangouts on Air. This is the feature that would enable people to broadcast their communication or presentation both on YouTube and through your Google+ page. It is a great way to have a "public" event or get more people involved in the conversation.

For educational purposes, many people think that the Google Hangouts on Air is a great alternative to expensive webinar solutions where you and up to 9 guests can hangout and discuss whatever topic takes your fancy and broadcast that conversation to the rest of the world. However, you definitely can also set it up to be a 'private' event when you do not want your broadcast seen by public.

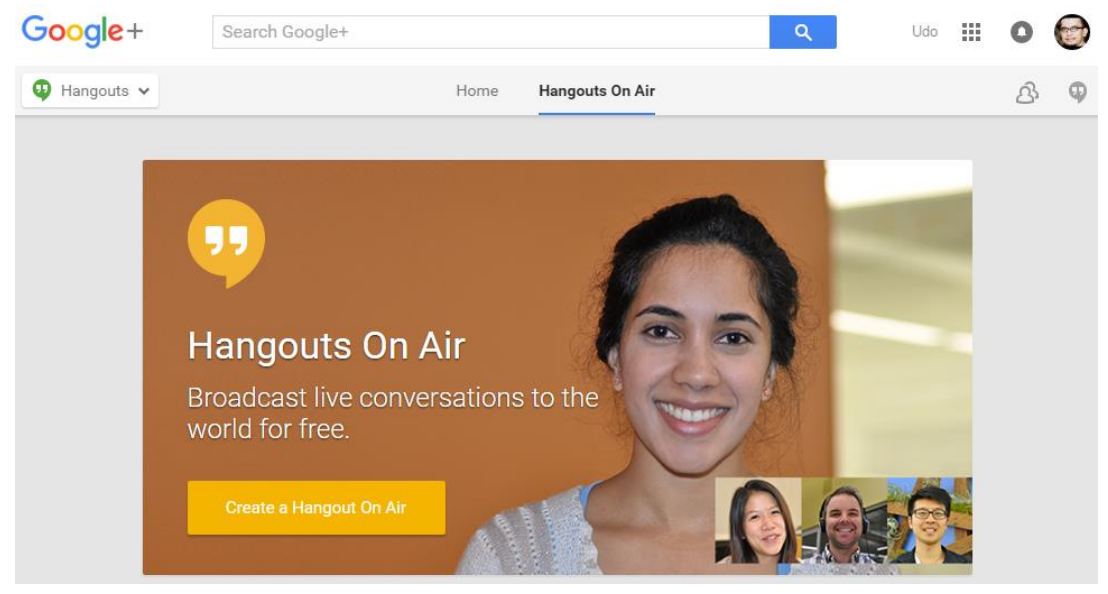


To make the best use of this Google Hangouts, a teacher need learn step by step procedures on how to use the Google Hangouts, starting how to create a Hangout to how to manage the setting of Hangout and how can you use all the features for your teaching. After that, the teacher also needs to show the students on how to use this wonderful application. This application is really good as a medium to reach your students when you are away for some reasons.

\section{Challenges}

As a virtual classroom will much rely on the availability of the internet connection, the provision of reliable internet network will be the most crucial challenge faced by teachers to use this Google Apps for Education. This what I have experienced during the last two years when I started to use these apps in my class. The internet network arroud our university is not reliable enough. A bad network will definitely make the communication among teachers and students not working really well. It takes like ten minutes, for instance, for the students to read a learning material I post in the Google Classroom. As the result, the learning process sometimes could not run well as expected. To deal with this, it is important for the teachers, lecturers, schools, or university to make sure that their internet capacity is sufficient for a smooth connection. In the case of my class, apart from reporting the IT man in our faculty to upgrade the capacity and to maintain a stong network around campus, I also remind students to have their own internet connection through their mobile devices. In case, the campus internet to their own personal wifi network.

Culture shock may be another challenge faced by both teachers and students in attending the virtual class and making use of these Google Applications. Some students may feel uncomfortable or confused at the beginning. Some others might think that the virtual class is not that important compared to conventional classroom where they can have a face to face interaction. To deal with this, teachers need to make sure that the students understand the importance of this virtual class from the beginning. In most cases, I believe that time will heal. What I found in my class, most students only experienced the shock for the first or the second meeting. They were all fine in the following meetings.

\section{Conclusion}

This paper has introduced and reported the use of Google Apps for Education for teaching writing in a university in Indonesia. It has discussed some reasons why these applications can be good media to help teachers make the writing class more effectively. The detailed information on how to use these apps for teaching writing online has also been described. Some challenges found in the filed have also been reported followed by some possible solution. Hopefully, this paper can inspire other teachers in the field on how to make use the Google Apps for Education (GAFE) to enhance the quality of our teaching.

\section{References}

Bijami M., Kashef S., \& Nejad M. (2013). Peer Feedback in Learning English Writing: Advantages and Disadvantages. Journal of Studies in Education, 3(4), 91.

Lander, Greg. (2014). 10 Tips on How to Use Google Plus Hangouts. http://www.jeffbullas.com/2013/12/04/10-tips-on-how-to-use-google-plus-hangouts/. Retrieved on 10/04/2016

Langan, J. (2005). College Writing Skills with Readings. New York: McGraw-Hill 
Lundstrom, K., \& Baker, W. (2009). To give is better than to receive: The benefits of peer review to the reviewer's own writing. Journal of Second Language Writing, 18, 30-43

Lewandowski, M. (2015). "Creating virtual classrooms (using Google Hangouts) for improving language competency." Language Issues: The ESOL Journal, 26(1), 37-42.

Neumann, C. (2014). 4 Important Reasons To Pair Mobile Devices With Interactive Whiteboards (And How To Do It!). https://www.tierneybrothers.com/AboutUs/NewsBlog/4ImportantReasonstoPairMobileDevic eswithInteractiveWhiteboardsandHowtoDoIt.aspx. Accessed on 26/11/2017

Noriah, I., Sumarni M., \& Nor, H. H. (2008). The Impact of Teacher Feedback on ESL Students' Writing Performance. Academic Journal of Social Studies, 8(1), 45-54

Paulus, TM. (1999). The effect of peer and teacher feedback on student writing. Journal of Second Language Writing, 8(3), 265-289

Zemach, D.E. \& Rumisek, L.A. (2005). Academic Writing from Paragraph to Essay. Oxford: Macmillan.

Whittaker, C. \& B. Tomlinson, Eds. (2013). Blended Learning in English Language Teaching: Course Design and Implementation. London: British Council.

Tusino. (2013). The Effectiveness Of Peer Editing To Improve The Students' Essay Writing Skill. Jurnal Penelitian Humaniora, 14 (2), 133-143. 